\title{
Agnieszka Budziewicz-Guźlecka
}

Uniwersytet Szczeciński

e-mail: agnieszka.budziewicz@wzieu.pl

\section{WYBRANE ASPEKTY SMART CITY \\ NA PRZYKLADZIE SZCZECINA \\ SELECTED ASPECTS OF SMART CITY ON THE EXAMPLE OF SZCZECIN}

DOI: $10.15611 /$ ie. 2017.4 .02

JEL Classification: P0

Streszczenie: $\mathrm{W}$ artykule podjęto próbę wyjaśnienia istoty inteligentnego miasta, zwracając uwagę, iż jest to pojęcie bardzo szerokie. Miasta pod względem koncepcji smart city są klasyfikowane przez różne mierniki, które zostały zaprezentowane w pracy. Zwrócono uwagę na programy, zarówno krajowe, jak i lokalne, które przyczyniają się do rozwoju inteligentnych miast i sprzyjają mu. W pracy zaprezentowano wybrane wyniki badań dotyczących opinii na temat Szczecina jako inteligentnego miasta. Celem artykułu jest wskazanie istoty inteligentnego miasta oraz wyników badań dla Szczecina. Metodą badawczą wykorzystaną w pracy jest ankieta przeprowadzona wśród studentów Uniwersytetu Szczecińskiego. Z przeprowadzonych badań wynika, iż respondenci wykazują chęć korzystania z aplikacji inteligentnego miasta, które przyczyniają się przede wszystkim do poprawy jakości życia.

Słowa kluczowe: inteligentne miasto, techniki i technologie przesyłu informacji, jakość życia, informacja.

Summary: This article attempts to clarify the nature of intelligent city, noting that it is a very broad concept. Cities in terms of the smart city concept are classified by various measures that were presented in the paper. Programs have been shown that contribute to and support the development of smart cities. The paper presents selected results of research on opinions about Szczecin as a smart city. The aim of the article is to indicate the essence of a smart city and research results for the city of Szczecin. The research method used in the work is a survey conducted on students of the University of Szczecin. The research shows that the respondents are willing to use the smart city application, which primarily contributes to the improvement of the quality of life.

Keywords: smart city, Information-Communication Technology (ICT), quality of life, information. 


\section{Wstęp}

$\mathrm{Na}$ rynku pojawia się coraz więcej produktów wykorzystujących zaawansowane technologie do zarządzania właściwie we wszystkich obszarach funkcjonowania miasta, a firmy prześcigają się w wizjach rozwoju miast przy użyciu ICT (technologii informacyjno-komunikacyjnych) oraz propozycjach projektów, które mogłyby zintegrować ich wirtualną i fizyczną przestrzeń.

Coraz częściej używa się słowa inteligentny, na przykład pojęć „,inteligentne miasto”, „inteligentny dom”, jednakże należy pamiętać, że pojęcie ,inteligentny” powinno być przypisywane istotom żywym. Mimo wszystko już powszechnie używa się również pojęcia „,inteligentne miasto”, czyli smart city. Ze względu na częste stosowanie pojęcie to zostało wprowadzone do powszechnego użycia.

Celem artykułu jest zidentyfikowanie aspektów, które pozwalają miasto uznać za inteligentne. Kluczowym celem artykułu jest przedstawienie istotności smart city oraz mierników wykorzystywanych do badań nad rozwojem inteligentnych miast. $\mathrm{W}$ artykule postawiono następującą hipotezę badawczą: koncepcja smart city jest bardzo szeroka, co powoduje konieczność ujednolicenia mierników inteligentnych miast. Hipoteza pomocnicza brzmi: umiejętność i chęć wykorzystywania aplikacji ICT usprawniających jakość życia przez mieszkańców miast przyczyni się do naturalnego rozwoju smart city. W pracy zaprezentowano wybrane wyniki badań dotyczące opinii wyrażanych na temat Szczecina jako inteligentnego miasta, wyrażonych przez osoby mieszkające i przebywające w tym mieście. Metodą badawczą do zebrania tychże była ankieta przeprowadzona wśród studentów drugiego i trzeciego roku studiów, studiujących w Szczecinie.

\section{Istota smart city}

Koncepcja smart city stanowi odpowiedź na przemianę, jaka dokonuje się w skali globalnej, dotyczącą budowy i funkcjonowania miast, które stają się ,inteligentne”, niezależnie od ich poziomu rozwoju. Transformacja ta dotyka wielorakich aspektów życia, począwszy od transportu, przez ekologię, energetykę, budownictwo czy też wypracowywanie nowych sposobów komunikacji z mieszkańcami, na przykład przez dialog z mieszkańcami w zakresie budżetu obywatelskiego.

Postępująca urbanizacja i związane z nią konsekwencje są obecnie kluczowym wyzwaniem dla władz miast. Świadczenie usług publicznych jest coraz kosztowniejsze, a zasoby naturalne są nadmiernie eksploatowane. Na nieistniejące wcześniej $\mathrm{w}$ tak dużym wymiarze problemy stara się odpowiedzieć koncepcja inteligentnego miasta, która pojawiła się na początku XXI wieku jako kontynuacja badań nad zrównoważonym rozwojem wspomożonym nowoczesnymi technologiami przesyłu informacji, w tym zwłaszcza w zakresie telekomunikacji i szeroko pojętej komunikacji i transportu [Kuder 2013]. Jednym z kluczowych i silnie rozwijanych kierunków, które wychodzą naprzeciw poprawie jakości życia społeczeństwa, mieszkańców 
miast, a więc - co za tym idzie - również samej atrakcyjności miast, jest koncepcja smart city. Miasto inteligentne to obszar o wysokiej możliwości i zdolności uczenia się oraz innowacji. To terytorium kreatywne, z szkolnictwem wyższym, z instytucjami badawczo-rozwojowymi, infrastrukturą cyfrową i technologiami przesyłu informacji i komunikacji, a także charakteryzujące się wysokim poziomem sprawności zarządzania [Komninos 2008].

Smart city, czyli inteligentne miasto, to miasto wykorzystujące zaawansowane technologie tak, aby poprawić jakość życia, zachować zasady zrównoważonego rozwoju, chronić środowisko naturalne i osiągnąć zakładane efekty, przy jak najniższych kosztach ponoszonych w długim okresie. Większość definicji smart city skupia się przede wszystkim na aspektach techniczno-technologicznych. Na przykład według Iñakiego Azkuny „miasto inteligentne wykorzystuje techniki i technologie informacyjno-komunikacyjne w celu zwiększenia interaktywności i wydajności infrastruktury miejskiej i jej komponentów składowych, a także do podniesienia świadomości mieszkańców" [Azkuna (red.) 2012]. Każde miasto jest inne, mierzy się z różnymi problemami i oczekiwaniami mieszkańców, ma odmienne uwarunkowania i możliwości rozwoju [Budziewicz-Guźlecka, Drab-Kurowska 2017].

Kluczowym atrybutem wskazującym stopień opanowania zasobów miasta (a więc podaży infrastruktury) wobec potrzeb, oczekiwań mieszkańców (a więc popytu na infrastrukturę) jest ranga efektów kształtujących jakość życia, a więc zadowolenia z zaspokajanych potrzeb mieszkańców. Inteligentne miasto to obszar składający się z trzech głównych elementów, które prezentuje rys. 1 .

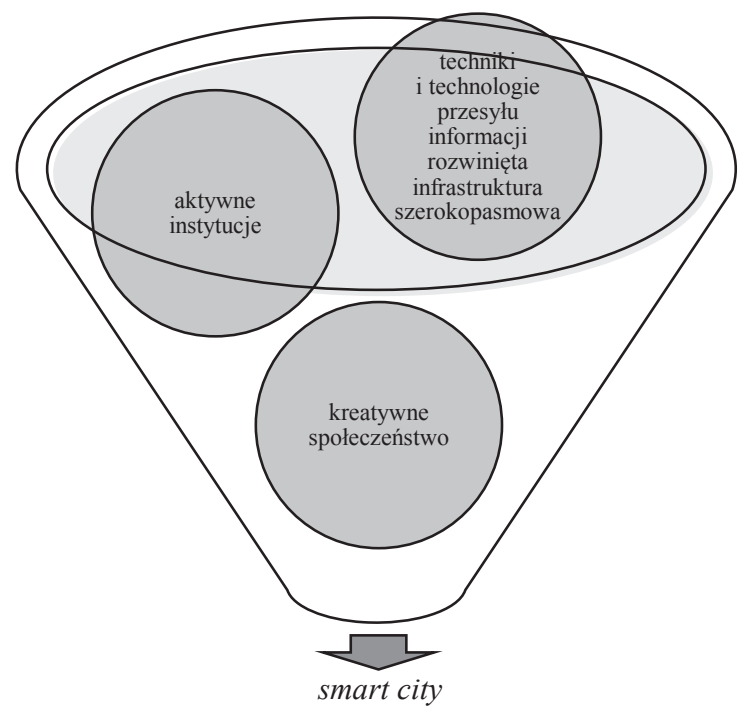

Rys. 1. Kluczowe elementy nieodzowne do rozwoju koncepcji smart city

Źródło: opracowanie własne. 
Podstawą rozwoju koncepcji smart city jest rozwinięta infrastruktura szerokopasmowa, cyfrowe przestrzenie, e-administracja, e-usługi oraz narzędzia on-line do zarządzania wiedzą. Bardzo istotne jest wsparcie instytucji, które powinny działać efektywnie, ale także procedury w zakresie tworzenia wiedzy, umożliwiające jej nabywanie, adaptację i rozwój. Pomimo nawet rozwiniętych systemów informacyjno-komunikacyjnych oraz powszechnego dostępu do sieci Internet, chęci wdrożenia wykorzystania możliwości, jaką dają te systemy, przez instytucje, jeżeli mieszkańcy danego miasta nie będą mieli umiejętności wykorzystania tychże możliwości, to koncepcja smart city nie będzie się rozwijała sprawnie.

Potrzebne jest kreatywne społeczeństwo, mające większą świadomość ekonomiczną i informatyczną, które intensywnie wykorzystuje wiedzę i możliwości nowoczesnych technologii [Drab-Kurowska 2011].

Smart city to „dobrze funkcjonujące przyszłościowe miasto tworzone przez sześć obszarów oraz oparte na aktywnym działaniu świadomych, niezależnych i decydujących o swoich losach obywateli" [Giffinger i in. 2007]. Wyróżnione obszary to:

- inteligentna gospodarka (smart economy) - konkurencyjność,

- inteligentna mobilność (smart mobility) - transport i ICT,

- inteligentne środowisko (smart environment) - zasoby naturalne,

- inteligentni ludzie (smart people) - kapitał społeczny i ludzki,

- inteligentne warunki życia (smart living) - jakość życia,

- inteligentne sprawowanie władzy (smart governance) - partycypacja.

Zasadniczym elementem wyróżniającym tę koncepcję spośród dotychczasowych modeli zrównoważonego rozwoju jest obecność „,mobilności” jako odrębnego, istotnego wymiaru określającego dostępność komunikacyjną, infrastrukturę teleinformatyczną oraz innowacyjne i bezpieczne systemy transportowe.

Problemy definicyjne wynikają z odmiennego postrzegania i podejścia do istoty smart city w różnych obszarach na świecie. W Unii Europejskiej i jej dokumentach strategicznych dotyczących inteligentnych miast nacisk położony jest w głównej mierze na ograniczenie emisji $\mathrm{CO}_{2}$ do atmosfery, czystą energię oraz oszczędności w jej zużyciu. Natomiast w Stanach Zjednoczonych miasta mogą być określane jako smart, gdy mają kapitał ludzki i społeczny, tradycyjną i nowoczesną infrastrukturę komunikacyjną (techniki i technologie komunikacyjne, ale też transport), ich rozwój jest zgodny z teorią rozwoju zrównoważonego, a partycypacyjny system rządów zapewnia lepszą jakość życia. Z kolei w Australii podejście do miasta inteligentnego koncentruje się na cyfrowych mediach i przemysłach kreatywnych [Murray i in. 2011].

Niektóre działania władz lokalnych mogą budzić wątpliwości, prowadząc do błędnego podejścia do koncepcji smart city, a więc nadmiernego skupiania się na inwestowaniu $\mathrm{w}$ zaawansowane techniki i technologie, bez realnego dostrzegania konfliktów i problemów występujących w miastach.

Jednakże tylko w drodze zastosowania wybranych rozwiązań z zakresu ICT możliwe jest zwiększanie wydajności infrastruktury komunikacyjnej, optymalizacja 
zużycia mediów dostarczanych mieszkańcom oraz organizacjom funkcjonującym na terenie miast, obniżanie kosztów obsługi administracyjnej czy optymalizacja procesów urbanizacyjnych [Chomiak-Orsa 2016].

Nowoczesne technologie wykorzystywane w różnych obszarach funkcjonowania miast nie są jednak niczym złym, pod warunkiem że władze lokalne pamiętają o współpracy z mieszkańcami, budowaniu partycypacji społecznej oraz podnoszeniu zdolności miast do przyciągania i utrzymywania wysokiej klasy specjalistów.

Jednocześnie rozwój inteligentnego miasta może być rozpatrywany jako tworzenie kooperującej sieci organizacji (publicznych), mających na celu dążenie do maksymalizacji dostarczanej wartości przez [Sobczak 2013]:

- zwiększenie efektywności zastosowania każdego z zasobów, zarówno materialnego, jak i niematerialnego ( $w$ tym szczególnie wiedzy), znajdującego się w posiadaniu, lub dostępnych dla tych jednostek,

- likwidację powielających się nakładów i czynności podejmowanych w tych jednostkach,

- zaoferowanie nowych, innowacyjnych usług, niemożliwych bądź trudnych do osiągnięcia bez współpracy poszczególnych jednostek.

Należy też pamiętać o wielu barierach budowy inteligentnego miasta skutecznie ograniczających płynność rozwoju tej koncepcji. Najważniejsze z nich to [Sobczak 2013]:

- bariery organizacyjne (tj. wyspowe, niezintegrowane rozwiązania IT; brak podejścia procesowego na poziomie urzędów),

- bariery mentalne (tj. niewielu decydentów administracji publicznej potrafi funkcjonować w cyfrowym świecie; oczekiwanie szybkich, pozytywnych efektów; brak rozumienia koncepcji smart city; obawa przed zmianą),

- bariery finansowe.

\section{Mierniki smart city}

Każdego roku powstaje wiele rankingów światowych miast. Są przygotowywane na podstawie zróżnicowanych kryteriów i często każdy z nich kładzie akcent na inny aspekt funkcjonowania miast. Jedne skupiają się na technologiach i ich wykorzystaniu, inne oceniają jakość życia czy też koncentrują się na rozwoju gospodarczym, bezpieczeństwie, ekologii. Są też rankingi dążące do uwzględnienia maksymalnie wielu kryteriów, a tym samym dążące do tworzenia zestawień w miarę uniwersalnych i obiektywnych.

Obecnie na świecie jest stosowanych kilka różnych rozwiązań koncepcji smart city. Należy wspomnieć o rankingu European do mierzenia poziomu rozwoju miast w aspekcie Smart City Model przygotowywanym już od 2008 roku na Uniwersytecie Technicznym w Wiedniu. European Smart City Model uwzględnia 6 obszarów funkcjonowania inteligentnych miast.

Podejście to pozwala rozszerzyć rozumienie rozwoju miejskiego poza technologię, która jest oczywiście elementem nieodzownym dla funkcjonowania smart city, 
ale nie jedynym. Podejście to nie jest również wąskim pojmowaniem konkurencyjności z punktu widzenia przedsiębiorstw funkcjonujących w mieście. Jednocześnie pozwala uniknąć podstawowych niebezpieczeństw związanych z podporządkowaniem strategii rozwoju miasta celowi podnoszenia konkurencyjności. Takimi zagrożeniami mogą być: zbytnia koncentracja na atrakcyjności inwestycyjnej lokalizacji (miasta), ograniczenie strategii do celów łatwych w komunikacji marketingowej (np. pozycja w rankingach konkurencyjności) lub zmniejszona chęć do współpracy pomiędzy obszarami miejskimi [Szczech-Pietkiewicz 2015]. W trzech pierwszych edycjach ranking dotyczył wyłącznie miast od 100 do 500 tys. mieszkańców. W edycji z 2015 r. zostały natomiast uwzględnione tylko miasta o liczbie mieszkańców od 300 tys. do 1 miliona, co spowodowało, iż niektóre z miast nie podlegały ocenie.

Do przykładowych rankingów związanych ze smart city można zaliczyć: Cities In Motion Index (IESE Business School), Global Smart City (Juniper Research), Networked Society City Index (Ericsson). Według Cities In Motion Index w roku 2016 miejsca na początku listy były następujące: 1. Nowy Jork, 2. Londyn, 3. Paryż, 4. San Francisco, 5. Boston. Według najnowszego raportu IESE Cities in Motion Index 2017 tylko dwa polskie miasta zakwalifikowały się do pierwszej setki zestawienia, a mianowicie Warszawa na 54. miejscu oraz Wrocław na miejscu 95. Większość dużych polskich miast przekracza dopuszczalne normy zanieczyszczenia powietrza, a to automatycznie wyklucza je z grona miast inteligentnych. Natomiast według Global Smart City w roku 2016 miejsca na początku listy były następujące: 1. Singapur, 2. Barcelona, 3. Londyn, 4. San Francisco, 5. Oslo. Z kolei ranking Networked Society City Index wskazał, że w roku 2016 miejsca na początku listy były następujące: 1. Sztokholm, 2. Londyn, 3. Singapur, 4. Paryż, 5. Kopenhaga. Można zauważyć, iż w każdym z rankingów występują inne miasta.

Wyzwań, przed którymi stają twórcy tego typu zestawień, jest wiele, gdyż chociażby bardzo trudno porównać miasta powyżej 10 mln mieszkańców z miastami zdecydowanie mniejszymi. Utrudnione jest również porównanie miast położonych w różnych strefach kulturowych.

Miasta analizowane mogą być za pomocą zestawu wskaźników dotyczących kapitału ludzkiego, spójności społecznej, gospodarki, zarządzania publicznego, partycypacji społecznej, środowiska naturalnego, mobilności i transportu, planowania przestrzennego, wydajności i zaawansowanych technologii.

W 2015 roku do serii norm ISO została wprowadzona norma ISO 37120 - Zrównoważony rozwój społeczny: wskaźniki dla usług miejskich i jakości życia.

Norma ISO 37120 jest pierwszym standardem ISO dla pomiarów miasta. To dokument obejmujący zestaw wskaźników pogrupowanych w obszary tematyczne dotyczące różnych aspektów funkcjonowania miasta. Wskaźniki zostały podzielone na 17 grup tematycznych: edukacja, straż pożarna i reagowanie kryzysowe, bezpieczeństwo, środowisko, ekonomia, finanse, rekreacja, zdrowie, telekomunikacja i innowacja, transport, zarządzanie, energia, schronienie, odpady stałe, woda i kanaliza- 
Agnieszka Budziewicz-Guźlecka

cja, ścieki, urbanistyka. Norma jest zestawem 100 wskaźników, 46 podstawowych i 54 dodatkowych. Ma być narzędziem do jednolitego sposobu raportowania stanu rozwoju miasta i ustalonym zestawem standardowych wskaźników, które zapewniają jednolite podejście do tego, co jest mierzone i jak pomiar ma być dokonany.

Wskaźnik nie określa jednak wartości minimalnej, którą miasto musi osiągnąć.

Miasta mogą otrzymać różne poziomy certyfikacji na podstawie liczby zgłoszonych i zweryfikowanych wskaźników zgodnie z normą ISO 37120. Certyfikacja prowadzona jest na pięciu poziomach:

- aspirujący (30-40 wskaźników podstawowych),

- brązowy (46-59 wskaźników, w tym 46 podstawowych + 0-13 dodatkowych),

- srebrny (60-75 wskaźników, w tym 46 podstawowych + 14-29 dodatkowych),

- złoty (76-90 wskaźników, w tym 46 podstawowych + 30-44 dodatkowych),

- platynowy (91-100 wskaźników, w tym 46 podstawowych + 45-54 dodatkowych).

Ze względu na dynamikę rozwoju miast certyfikacja musi być odnawiana co rok.

Każdy z powyższych wskaźników ma swoje wady i zalety, norma ISO jest próbą określenia za pomocą wskaźników obiektywnych wyników pomiaru inteligentnego miasta.

\section{Programy sprzyjające rozwojowi koncepcji smart city}

Według wcześniej wskazanych mierników jedynie dwa miasta w Polsce znajdują się na listach rankingowych. Z kolei według najnowszej normy ISO 37120 jedynie Gdańsk otrzymał certyfikat potwierdzający spełnienie podstawowych wskaźników. Konieczne jest podjęcie wielu działań na poziomie zarówno krajowym, jak i lokalnym, by wspomóc pozytywne zmiany w obszarze rozwoju smart city. Do programów sprzyjających koncepcji smart city należą przede wszystkim:

Program Zintegrowanej Informatyzacji Państwa, który został zaktualizowany w 2016 roku ze względu na to, iż wcześniej wystąpiły pewne błędy i brak spójności we wdrażanym programie. Do błędów można zaliczyć: po stronie administracji - niewystarczające kompetencje dotyczące zamawiania, projektowania, budowy i utrzymania systemów informatycznych - w praktyce oznacza to asymetrię pozycji państwa $\mathrm{w}$ stosunku do firm informatycznych, u których są kupowane systemy [https://www.gov. $\mathrm{pl} /$ cyfryzacja/program-zintegrowanej-informatyzacji-panstwa]. Wśród błędów można także wymienić: brak kompatybilności pomiędzy systemami i rejestrami; te same informacje są gromadzone równolegle w różnych bazach, co powoduje częste ich powielanie; gromadzone dane nie są ponownie wykorzystywane.

Realizacja programu ma doprowadzić do tego, aby społeczeństwo w rzeczywisty sposób odczuło pozytywne efekty zmiany cywilizacyjnej, jaką niesie ze sobą cyfryzacja oraz ułatwienia w realizacji usług związanych z prowadzeniem działalności gospodarczej.

Ze względu na to, iż e-kompetencje są bardzo istotne dla koncepcji smart city istotna jest edukacja od najmłodszych lat, gdyż to są obecni i przyszli mieszkańcy 
inteligentnych miast. Edukacji od najmłodszych lat sprzyja Projekt Ogólnopolskiej Sieci Edukacyjnej (OSE), mający w swoich założeniach stworzenie sieci dostępu do Internetu, która łączyłaby wszystkie szkoły ma terenie Polski. Sieć ta ma być siecią wirtualną, która będzie oparta na infrastrukturze szerokopasmowej. Projekt ten ma na celu nie tylko dostarczanie szkołom usług dostępu do Internetu o przepustowości co najmniej $100 \mathrm{Mb} / \mathrm{s}$ wraz z usługami bezpieczeństwa, ale także dostarczanie szkołom treści edukacyjnych $\mathrm{i}$ - co bardzo istotne z punktu koncepcji smart city - również wsparcie szkół w procesie kształcenia umiejętności cyfrowych.

Wdrażanie projektu pozwoli na:

1) diametralną zmianę zgodnie $z$ dynamicznym postępem cywilizacyjnym w sposobie edukacji uczniów dzięki przejściu z edukacji analogowej w kierunku edukacji cyfrowej (wraz z bezpiecznym korzystaniem z treści udostępnionych w sieci),

2) wprowadzenie nowych form kształcenia, a także nowych programów nauczania umiejętności cyfrowych (przez np. powszechną naukę programowania), a dzięki temu wzrost kompetencji.

Tabela 1. Podstawowe informacje na temat wydatków w województwie zachodniopomorskim sprzyjające rozwojowi inteligentnego miasta

\begin{tabular}{|l|l|r|r|c|}
\hline $\begin{array}{c}\text { Symbol } \\
\text { osi }\end{array}$ & \multicolumn{1}{|c|}{ Nazwa osi } & $\begin{array}{c}\text { Wydatki } \\
\text { kwalifikowalne } \\
\text { w podpisanych } \\
\text { umowach } \\
\text { (w euro) }\end{array}$ & $\begin{array}{c}\text { Wydatki } \\
\text { kwalifikowalne } \\
\text { w podpisanych } \\
\text { umowach } \\
(\% \text { wykorzystania) }\end{array}$ & $\begin{array}{c}\text { Liczba (z) } \\
\text { realizowanych } \\
\text { projektów }\end{array}$ \\
\hline OP1 & $\begin{array}{l}\text { Gospodarka, innowacje, } \\
\text { nowoczesne technologie }\end{array}$ & 119048117 & $29,58 \%$ & 28 \\
\hline OP2 & Gospodarka niskoemisyjna & 15593369 & $6,09 \%$ & 24 \\
\hline OP3 & $\begin{array}{l}\text { Ochrona środowiska i adaptacja } \\
\text { do zmian klimatu }\end{array}$ & 10405445 & $12,12 \%$ & 24 \\
\hline OP4 & Naturalne otoczenie człowieka & 20618423 & $19,39 \%$ & 5 \\
\hline OP5 & Zrównoważony transport & 70795994 & $21,29 \%$ & 8 \\
\hline OP6 & Rynek pracy & 38712903 & $19,94 \%$ & 55 \\
\hline OP7 & Włączenie społeczne & 8363712 & $5,42 \%$ & 14 \\
\hline OP8 & Edukacja & 10217684 & $9,63 \%$ & 53 \\
\hline OP9 & Infrastruktura publiczna & 0 & $0,00 \%$ & 0 \\
\hline
\end{tabular}

Źródło: opracowanie własne na podstawie sprawozdania rocznego z wdrażania Regionalnego Programu Operacyjnego Województwa Zachodniopomorskiego 2014-2020 za rok 2016.

Fundusze europejskie na lata 2014-2020 sprzyjające rozwojowi smart city na terenie Polski są wdrażane przez kilka programów operacyjnych:

- Infrastruktura i Środowisko (PO IiŚ): środki z programu są i będą przeznaczane na zmniejszenie emisyjności gospodarki, ochronę środowiska, rozwój sieci drogowej TEN-T i transportu multimodalnego, infrastrukturę drogową miast, rozwój transportu kolejowego, rozwój transportu zbiorowego, niskoemisyjnego 
w miastach, poprawę bezpieczeństwa energetycznego, ochronę dziedzictwa kulturowego i rozwój zasobów kultury, wzmocnienie systemu ochrony zdrowia.

- Wiedza. Edukacja, Rozwój (PO WER): środki z programu są i będą przeznaczone na aktywizację zawodową, walkę z ubóstwem, propagowanie inwestowania w edukację.

- Polska Cyfrowa: środki z programu są i będą przeznaczane na zapewnienie powszechnego dostępu do Internetu, zwiększenie zastosowania technologii typu e-administracja i otwarty urząd.

Podstawowe dane identyfikacyjne i finansowe osi priorytetowych w województwie zachodniopomorskim prezentuje tab. 1.

Jak wynika z tab. 1, wszystkie osie sprzyjają rozwojowi miasta inteligentnego.

\section{Wybrane wyniki badań oraz przykłady najnowszych wdrożeń koncepcji smart city na przykładzie Szczecina}

Ze względu na powszechność stosowania pojęcia „inteligentne miasto” i identyfikowania się mieszkańców poszczególnych miast jako osób żyjących w smart city przeprowadzono badanie ankietowe w mieście Szczecin. Zostało ono przeprowadzone wśród studentów Uniwersytetu Szczecińskiego w październiku 2017 roku w celu poznania opinii dotyczących postrzegania miasta Szczecin jako smart city. Badanie realizowano wśród studentów II i III roku pierwszego stopnia oraz drugiego roku drugiego stopnia. Wyeliminowano (nie poddano badaniu) studentów z roku pierwszego ze względu na potencjalnie zbyt krótki czas przebywania tychże studentów w Szczecinie, co mogłoby zakłócić wyniki badań. Wykorzystano badanie bezpośrednie - ankietę (rozdawaną), której zaletami są krótki czas pomiaru, wysoka zwrotność i wysoki stopień kontroli badań. Otrzymano 164 prawidłowo wypełnionych ankiet. W pracy przedstawiono wybrane wyniki badań.

Odpowiedzi respondentów dotyczące pytania, czy Szczecin można nazwać miastem inteligentnym, prezentują się następująco: z przeprowadzonego badania wynika, że 95 osób (58\%) uważa, że Szczecin można uznać za miasto inteligentne, 30 osób (18\%) uznało, że nie można uznać tegoż miasta za inteligentne, a aż $24 \%$ nie potrafiło udzielić jednoznacznej odpowiedzi.

Ze względu na to, iż partycypacja mieszkańców w tworzeniu inteligentnego miasta jest elementem nieodzownym, zadano pytanie, czy również osoby, które nie są mieszkańcami Szczecina, powinny mieć możliwość zgłaszania propozycji udogodnień w zakresie smart city, co zaprezentowano na rys. 2.

Odpowiedzi prezentują, iż 125 osób (76\%) wskazało, iż osoby niebędące mieszkańcami Szczecina powinny mieć możliwość zgłaszania propozycji udogodnień w zakresie smart city, natomiast 21 osób (13\%) nie miało zdania w tym zakresie, a 18 osób (11\%) było przeciwnych. Słuszne jest większościowe wskazanie możliwości wprowadzenia udogodnień przez osoby niebędące mieszkańcami ze względu na 


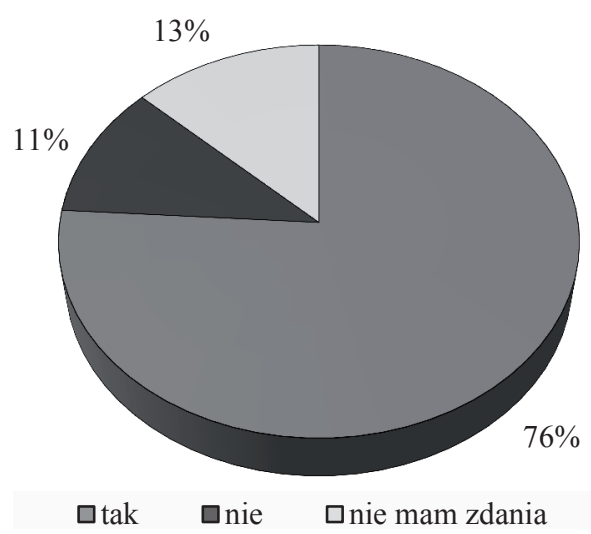

Rys. 2. Możliwość zgłaszania propozycji udogodnień w zakresie inteligentnego miasta przez osoby niebędące mieszkańcami, np. turystów czy studentów

Źródło: opracowanie własne.

wskazanie praktycznie przydatnych udogodnień przez doraźnie korzystających turystów czy też studentów.

Odnośnie do partycypacji społeczeństwa zadano również pytanie, czy osoby niebędące mieszkańcami powinny mieć także możliwość oddania głosu dotyczącego projektów z budżetu obywatelskiego, co zaprezentowano na rys. 3 .

Z badań wynika, że ponad $90 \%$ (149 osób) wskazało, iż osoby niebędące mieszkańcami Szczecina nie powinny mieć możliwości oddania głosu w budżecie obywatelskim. Natomiast 10 osób (6\%) wskazało, iż taką możliwość powinny mieć takie

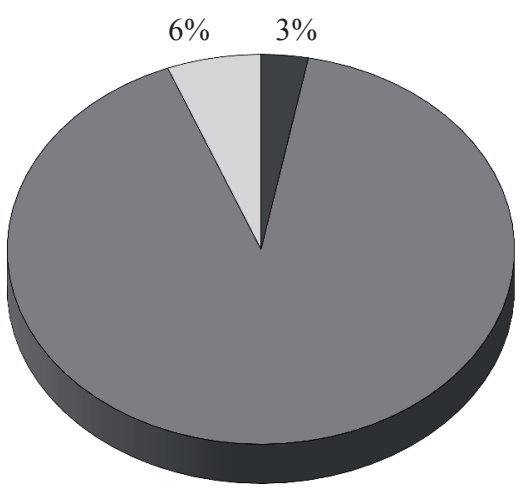

$91 \%$

$\square$ tak $\square$ nie $\quad \square$ nie mam zdania

Rys. 3. Możliwość głosowania w budżecie obywatelskim przez osoby niebędące mieszkańcami Szczecina Źródło: opracowanie własne. 
osoby, wskazując (wypowiedź z wywiadu pogłębionego), iż osoby, które być może chcą się związać ze Szczecinem, chciałyby mieć wpływ już teraz na to, co będzie w przyszłości.

Jednym z pytań zadanych respondentom była ocena chęci wykorzystania $\mathrm{w}$ przyszłości wybranych aplikacji. Wyniki prezentuje rys. 4 .

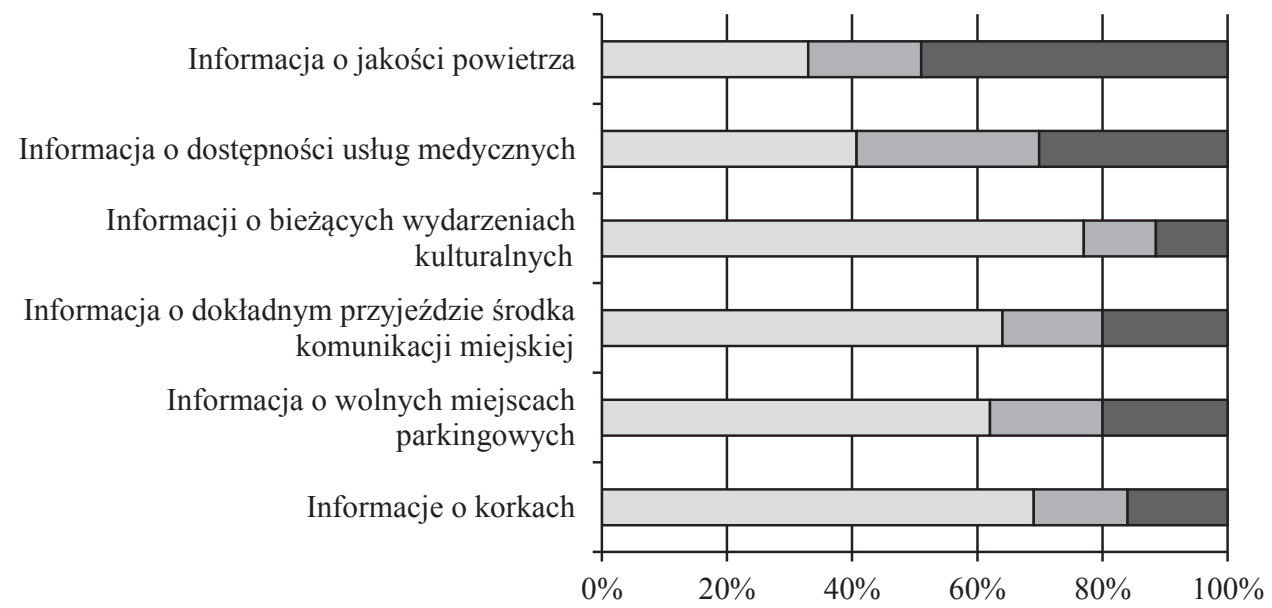

$\square$ tak $\square$ nie $\square$ nie mam zdania

Rys. 4. Chęć wykorzystania w przyszłości wybranych aplikacji

Źródło: opracowanie własne.

Najwięcej respondentów, bo aż 129 osób (77\%), wskazało chęć wykorzystania aplikacji dotyczącej bieżących wydarzeń kulturalnych. Ponad 60\% wykazało zainteresowanie aplikacjami dotyczącymi: korków w mieście (113 osób, czyli 69\%), dokładnej godziny przyjazdu środka komunikacji miejskiej, zgodnie z bieżącą sytuacją na drogach (105 osób, czyli 64\%) oraz wolnych miejsc parkingowych (102 osoby, czyli 62\%). Aplikacją dotyczącą usług medycznych było zainteresowanych 66 osób, czyli 40,5\%, co może wynikać z faktu, iż studenci jako grupa badawcza są osobami stosunkowo młodymi, niekorzystającymi jeszcze zbyt często z usług medycznych, co powoduje trudność przewidzenia również u niech chęci korzystania z takiej aplikacji. Jedynie 33\% respondentów (czyli 54 osoby) wykazało zainteresowanie aplikacją informującą o jakości powietrza. Wynikać może to z małej świadomości ekologicznej, ale przede wszystkim prawdopodobnie z braku problemów z jakością powietrza w Szczecinie obecnie.

W Szczecinie - jako pierwszym mieście w Polsce - zostanie wprowadzony pilotażowy projekt mający na celu wdrożenie wertykalnego zastosowania aplikacji tzw. Internetu Rzeczy Smart City. Za główny cel tegoż programu pilotażowego uważane jest sprawdzenie możliwości zastosowania technik i technologii do monitorowania 
zagrożeń, które mogą wynikać ze zmian klimatu na terenie Szczecina oraz kolejnych, przyszłych zastosowań Internetu Rzeczy w ramach wdrażanych i planowanych w mieście rozwiązań wspierających rozwój inteligentnych miast. Zakres tegoż pilotażu dotyczy zdalnego pomiaru temperatury w 10 punktach miasta przez rozmieszczone urządzenia sensoryczne, które pomogą badać zjawisko miejskiej wyspy ciepła. Miejska wyspa ciepła (MWC) to ogólne zjawisko, które towarzyszy architekturze miejskiej, szczególnie asfaltowo-betonowej. Należy do negatywnych rezultatów urbanizacji oraz koncentracji aktywności społeczeństwa w miastach. Są to tereny zurbanizowane, zazwyczaj wypełnione gęstą zabudową, a co za tym idzie - pozbawione zieleni oraz zbiorników wodnych. Cechują się zazwyczaj wyższą temperaturą od terenów okołomiejskich czy wiejskich.

Realizacja takiego projektu daje możliwość praktycznego wdrożenia miejskich planów adaptacji do zmian klimatu. Pozwoli na obserwację zmian skokowych temperatury na terenie miasta, obserwację obszarów niezabudowanych, ale także kształtowanie polityki zagospodarowywania terenów pod przyszłą zabudowę.

W Szczecinie w najbliższych miesiącach (koniec roku 2017 i początek roku 2018) zostaną zainstalowane pierwsze miejskie stacje szybkiego ładowania. Zostaną one wyposażone w dwa punkty do ładowania pojazdów elektrycznych. W kolejnych miesiącach miasto planuje instalacje kolejnych dwóch stacji szybkiego ładowania oraz czterech stacji ładowania wolnego.

\section{Zakończenie}

Koncepcja inteligentnego miasta zawiera w sobie bardzo wiele obszarów. Przede wszystkim powinna ukierunkowywać się na ułatwianie życia zwykłym mieszkańcom. Może to być osiągane dzięki wprowadzaniu i wykorzystaniu nowoczesnych technik i technologii (w postaci na przykład aplikacji), ale także inwestycjom w społeczeństwo, jego umiejętności oraz w wiedzę.

Inteligentne miasta nie powinny skupiać się wyłącznie na zastosowaniu technologii informatycznych. Jest to oczywiście bazą dla inteligentnego miasta, ale przede wszystkim promowania wysokiej jakości życia. Istotne jest, aby wdrażanie inteligentnych rozwiązań nie przyczyniało się do wykluczenia żadnej z grup społecznych, dlatego tak istotne jest również pogłębianie e-umiejętności wśród mieszkańców.

Istotna jest edukacja społeczeństwa w zakresie wykorzystania technologii ICT. Jest to nieodzowny element rozwoju społeczeństwa informacyjnego, a co za tym idzie - kreatywności mieszkańców miast w inicjowaniu koncepcji smart city, a wcześniej umiejętności wykorzystania wdrażanych zmian rozwojowych w miastach na bazie rozwiniętych technik ICT. 


\section{Literatura}

Azkuna I. (red.), 2012, Smart Cities Study: International STUDY on the Situation of ICT, Innovation and Knowledge in Cities, The Committee of Digital and Knowledge-based Cities of UCLG, Bilbao.

Budziewicz-Guźlecka, A., Drab-Kurowska, A. 2017, The analysis of selected issues pertaining to e-administration in poland in the context of smart city, Nordic and Baltic Journal of Information and Communications Technologies, nr 1, s. 17-32.

Chomiak-Orsa I., 2016, Znaczenie technologii informacyjno-komunikacyjnych w zrównoważonym rozwoju miast, Zeszyty Naukowe Politechniki Częstochowskiej. Zarządzanie, (23, t. 1), s. 36-45.

Drab-Kurowska A., 2011, Wykorzystanie technologii informatycznych w komunikacji marketingowej, Zeszyty Naukowe Uniwersytetu Szczecińskiego nr 651, Ekonomiczne Problemy Usług nr 68, Drogi dochodzenia do społeczeństwa informacyjnego: stan obecny, perspektywy rozwoju i ograniczenia, t. 2, s. 674-681.

Giffinger R., Fertner C., Kramar H., Kalasek R., Pichler-Milanoviü N., Meijers E., 2007, Smart Cities: Ranking of European Medium-Sized Cities, Centre of Regional Science (SRF), Vienna University of Technology, Vienna.

https://s3.amazonaws.com/academia.edu.documents/40878405/gmil_05_2014_int.pdf?AWSAccessKeyId=AKIAIWOWYYGZ2Y53UL3A\&Expires $=1512671818 \&$ Signature $=$ MskRaRqUe8NgH4QLF78IICP\%2FKyg\%3D\&response-content-disposition=inline $\% 3 \mathrm{~B} \% 20$ filename $\% 3 \mathrm{DSmart}$ City_-_miasto_przyszlosci.pdf.

https://www.gov.pl/cyfryzacja/program-zintegrowanej-informatyzacji-panstwa.

Komninos N., 2008, Intelligent Cities and Globalisationof Innovation Networks, Routledge, London and New York.

Kuder W., 2013, Smart cities, Eurogospodarka, nr 9.

Murray A., Minevich M., Abdoullaev A., 2011, Being smart about smart cities, Searcher, vol. 19, iss. 8, Special Section.

Sobczak A., 2013, Założenia modelu dostarczenia wartości z budowy inteligentnego miasta. Technologie informatyczne w administracji publicznej i stużbie zdrowia, GMiL, TIAPISZ, Warszawa.

Szczech-Pietkiwicz E., 2015, Smart city - próba definicji i pomiaru. Gospodarka lokalna w teorii i praktyce, Prace Naukowe Uniwersytetu Ekonomicznego we Wrocławiu nr 391, Wydawnictwo Uniwersytetu Ekonomicznego we Wrocławiu, Wrocław. 